\title{
Inter-Method Differences in the Measurement of Some Specific Plasma Proteins: Commutability of Control Materials
}

\author{
Laura Arcangeli ${ }^{1}$, Paolo Cueroni ${ }^{2}$, Carlo Franzini ${ }^{3}$, Giovanna Galletta ${ }^{3}$, Alessandra Moschini ${ }^{3}$ and \\ Luisa Scapellato ${ }^{3}$ \\ 1 Laboratorio Analisi, Ospedale Caduti Bollatesi, Bollate (Milano), Italy \\ 2 Laboratorio Analisi, Ospedale C. Ondoli, Angera (Varese), Italy \\ 3 Universita' di Milano, Istituto di Scienze Biomediche, Ospedale L. Sacco, Milano, Italy
}

\begin{abstract}
Summary: We compared the inter-method differences shown by control materials and by patients' sera for the measurement of some plasma proteins in the same pair of analytical systems. Sets of 100 to 110 samples of patients' sera and of 18-19 control materials, including the recently available CRM 470, were assayed with up to five automatic analytical systems, in two different experiments. About 5500 values were produced and assessed statistically. Materials (either patients' sera or control materials) were considered non-commutable (i. e. exhibiting significantly different inter-method behaviour) when their distance from the regression line in a stated pair of methods exceeded 3 standard deviations. According to this criterion, less than $1.5 \%$ of the patients' sera, and an even lower proportion of control materials were non-commutable. However, the inter-method behaviour of control materials was usually slightly different from that of patients' sera. Some systematic inter-method difference in the measurements on patients' sera may therefore exist, even though inter-method equivalence has been demonstrated with control materials.
\end{abstract}

\section{Introduction}

Plasma protein measurements show great variability between laboratories (1), mainly due to calibration problems $(1,2)$. The purpose of calibration is to ensure that the results from patients' sera are as close as possible to the "true" value, and that the results from different procedures are as close as possible to each other. In practice, calibration is performed using "materials", mostly provided by industry; for such materials to serve the expected purpose, they have to show inter-method properties comparable to those of patients' sera. This characteristic, known as commutability, was first studied for enzyme materials (3). Occurrence of non-commutability has been reported for a variety of non-enzymatic components $(4-6)$.

Here we report the results from two experiments, using different analytical systems, and planned to assess the commutability of a number of commercial control materials for the immunoassay of certain serum proteins. The two experiments involved a variable number of laboratories (two to three), analytical systems (four to five), serum proteins (two to four), and control materials (eighteen to nineteen). The second experiment also included a certified reference material (CRM 470).

\section{Materials and Methods}

Different sets of from 100 to 110 samples of fresh patients' serum, covering wide intervals of concentration, were used in the two experiments. A total of 26 commercial control materials, either lyophi- lized or liquid, were also used (tab. 1). The CRM 470 was obtained by BCR, Brussels (courtesy of Beckman Analytical, Milano).

Immunoglobulins $A, G$ and $M(\operatorname{IgA}, \operatorname{IgG}, \operatorname{Ig} M)$ and transferrin were measured in the patients' sera (in duplicate) and in the control materials (four replicates), using five automatic systems, based on immuno-turbidimetry (AU 560, Olympus; and Specific Plus, Kone) or immunonephelometry (QM 300, Kallestad; BNA, Behring; and APS 360 , Beckman). Each system was operated with the reagents and the calibrators supplied by the respective manufacturer. Between the first and the second experiment some modifications in the operating protocol of the AU 560 system were introduced, including modified anti-sera dilution ratios, modified sample volume fractions, and new lots of anti-sera and calibrators.

Analytical imprecision was calculated from duplicate results on patients' sera. Mean values from duplicate or quadruplicate measurements were used for further calculations. The inter-method relationship in the measurement of patients' sera with pairs of methods was assessed by means of linear regression, calculated according to the standardized principal component model (8); the residual standard deviation was computed as a measure of the dispersion around the line. Results from the AU 560 system were consistently assigned the $\mathrm{x}$-axis, in order to have a common comparison basis for the other systems.

For the assessment of commutability, $y^{\prime}$-values were computed from each set of $x$-values (patients' sera) using the relevant regression equation; the differences $\left[y-y^{\prime}\right]$ (residuals) were devided by their standard deviation to yield the "normalized residuals". Normalized residuals were also calculated for the control materials. Any material (patient serum or control material) showing a normalized residual outside the \pm 3 interval was considered non-commutable (9). About 5500 single analytical values vere produced: nonc was excluded from statistical calculations.

\section{Results}

Table 2 shows the within-run imprecision of the five analytical systems at different protein concentration values. 
Results of the methods comparison on patients' sera are shown in figures 1 and 2; the statistical evaluation of the inter-methods relationships is shown in table 3.

The distribution quantities (mean, SD, and number outside the \pm 3 interval) of the two populations of normalized residuals, from patients' sera and control materials respectively, are listed in table 4 ; the normalized residuals of the CRM 470 are listed in the table on a separate column.

In figure 3 the inter-method behaviour of the control materials and of the patients' sera are compared for some representative pairs of methods. Two examples of

Tab. 1 Control materials used in the two experiments.

\begin{tabular}{|c|c|c|c|c|c|}
\hline Exp. & Material & Manufacturer & Physical state & Matrix & $\begin{array}{l}\text { Specific for } \\
\text { serum proteins }\end{array}$ \\
\hline I \& II & Monitrol I & Baxter & lyophilized & human & no \\
\hline I \& II & Monitrol II & Baxter & lyophilized & human & no \\
\hline I \& II & Human Protein Reference Serum & Orion & lyophilized & human & yes \\
\hline I \& II & Precinorm U & Boehringer & lyophilized & human & no \\
\hline $1 \& 11$ & Precinorm Protein & Boehringer & liquid & human & yes \\
\hline I & Seronorm Human & Nycomed & lyophilized & human & no \\
\hline I & Sernorm Protein & Nycomed & lyophilized & human & yes \\
\hline I \& II & Bio-rad 1 & Biorad & lyophilized & hüman & no \\
\hline $1 \& I I$ & Bio-rad 2 & Biorad & lyophilized & human & no \\
\hline I \& II & Bio-rad 3 & Biorad & lyophilized & human & no \\
\hline I & Bio-rad 4 & Biorad & lyophilized & human & no \\
\hline I \& II & Ortho Cervinia & Ortho & lyophilized & human & no \\
\hline I & Decision Level 1 & Beckman & liquid & human & no \\
\hline I & Decision Level 2 & Beckman & liquid & human & no \\
\hline I & Decision Level 3 & Beckman & liquid & human & no \\
\hline I & Kontrollagen L & Behring & lyophilized & human & no \\
\hline I & Kontrollagen LP & Behring & lyophilized & human & no \\
\hline II & $\mathrm{N} / \mathrm{T}$ & Behring & liquid & human & yes \\
\hline II & CRM 470 & $\mathrm{BCR}$ & lyophilized & human & yes \\
\hline II & Vigil PRx 1 & Beckman & liquid & human & yes \\
\hline II & Vigil PRx 2 & Beckman & liquid & human & yes \\
\hline 11 & Vigil PRx 3 & Beckman & liquid & human & yes \\
\hline II & Liquicheck 1 & Biorad & liquid & human & yes \\
\hline II & Liquicheck 2 & Biorad & liquid & human & yes \\
\hline
\end{tabular}

Tab. 2 Analytical (within-series) imprecision of the five systems, from duplicate results, at two concentration levels (Lo and $\mathrm{Hi}$ ).

\begin{tabular}{|c|c|c|c|c|c|c|c|c|c|}
\hline \multirow[t]{2}{*}{ Protein } & \multirow[t]{2}{*}{ System } & \multirow[t]{2}{*}{ Exp. } & \multicolumn{2}{|l|}{$\mathrm{n}$} & \multicolumn{2}{|c|}{ Mean $(g / l)$} & & \multicolumn{2}{|c|}{ CV (\%) } \\
\hline & & & Lo & $\mathrm{Hi}$ & Lo & $\mathrm{Hi}$ & & Lo & $\mathrm{Hi}$ \\
\hline $\operatorname{Ig} A$ & AU 560 & I & 56 & 44 & 12.2 & 28.9 & & 1.23 & 1.86 \\
\hline IgA & AU 560 & I & 55 & 45 & 1.95 & 6.54 & & 1.66 & 1.02 \\
\hline IgM & AU 560 & I & 55 & 45 & 1.18 & 3.63 & & 0.80 & 1.45 \\
\hline IgM & AU 560 & II & 55 & 55 & 1.67 & 4.87 & & 3.31 & 4.64 \\
\hline Transferrin & $A U 560$ & I & 51 & 49 & 1.94 & 3.08 & & 2.32 & 2.31 \\
\hline Transferrin & $A U 560$ & II & 55 & 55 & 1.73 & 3.41 & & 3.62 & 3.88 \\
\hline IgG & QM 300 & I & 55 & 45 & 13.3 & 30.9 & & 2.83 & 2.30 \\
\hline IgA & QM 300 & I & 52 & 48 & 1.96 & 7.58 & & 3.26 & 3.19 \\
\hline IgM & QM 300 & 1 & 53 & 47 & 0.92 & 3.25 & & 4.30 & 5.38 \\
\hline IgM & QM 300 & II & 55 & 55 & 1.29 & 3.78 & & 3.90 & 3.04 \\
\hline Transferrin & QM 300 & I & 43 & 57 & 2.25 & 3.49 & & 1.85 & 2.39 \\
\hline Transferrin & QM 300 & II & 55 & 55 & 1.82 & 3.48 & & 5.60 & 5.25 \\
\hline IgG & SPECIFIC & I & 50 & 50 & 13.7 & 30.8 & & 1.56 & 2.19 \\
\hline IgA & SPECIFIC & I & 46 & 54 & 1.67 & 6.68 & & 3.35 & 4.35 \\
\hline IgM & SPECIFIC & I & 53 & 47 & 1.13 & 4.51 & & 5.24 & 2.47 \\
\hline Transferrin & SPECIFIC & I & 50 & 50 & 2.23 & 3.40 & & 1.34 & 1.37 \\
\hline IgM & BNA & I & 56 & 44 & 1.62 & 5.57 & & 3.29 & 1.46 \\
\hline IgM & BNA & II & 55 & 55 & 2.11 & 6.32 & & 1.62 & 3.46 \\
\hline Transferrin & BNA & II & 55 & 55 & 1.91 & 3.62 & - & 3.30 & 2.85 \\
\hline IgM & APS 360 & II & 55 & 55 & 1.48 & 4.31 & $\cdot 6$ & 1.83 & 1.53 \\
\hline Transferrin & APS 360 & II & 55 & 55 & 1.70 & 3.33 & & 1.74 & 1.48 \\
\hline
\end{tabular}


inter-method behaviour of control materials overlapping that of patients' sera (diagrams $3 a$ and $3 b$ ), and two examples of inter-method behaviour of control materials systematically different from that of patients' sera (diagrams $3 \mathrm{c}$ and $3 \mathrm{~d}$ ) are shown. Only two materials (circled in diagram 3d) show lack of commutability, according to the criterion chosen.
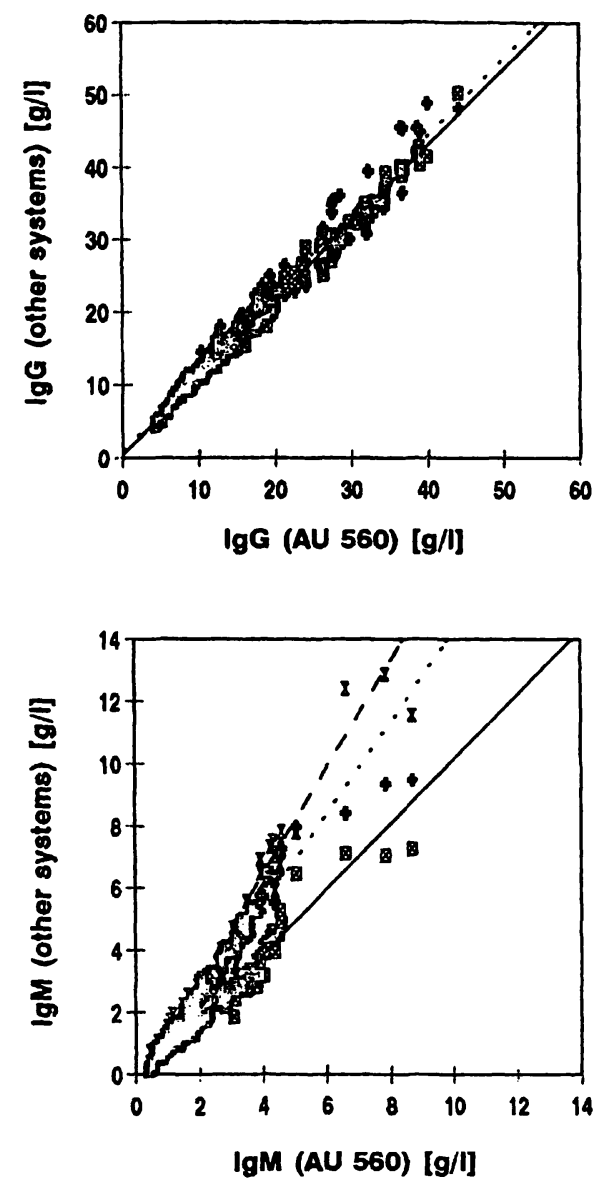

Fig. 1 Method comparison on patients' sera (from 100 to 110 samples): results from experiment $I$. For uniform comparison, the values from the AU 560 system were consistently assigned the $x$ axis, and the results from the altemative analytical systems were

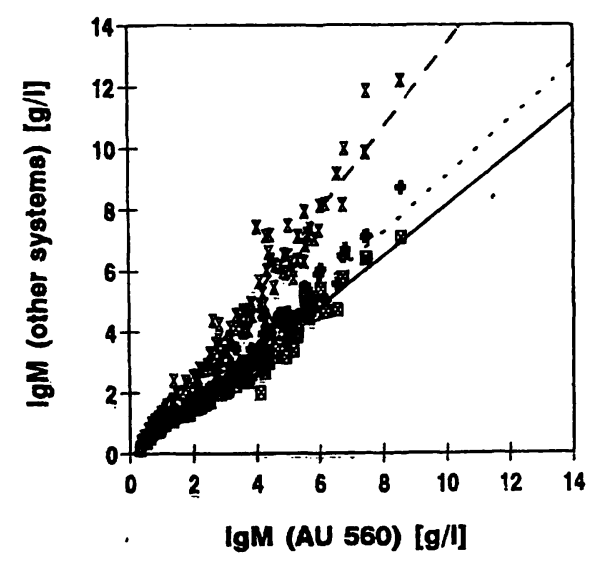

Fig. 2 Same as figure 1, results from experiment II.

$(-\otimes):$ QM 300

$(\cdots+\cdots+)$ : Specific

$(--8):$ BNA

\section{Discussion}

Casual and systematic inter-method differences in the measurement of some plasma proteins are confirmed by our results (fig. 1 and 2, tab. 3). Whilst it seems reasonable to speculate that matrix effects and/or molecular heterogeneity are mainly responsible for the former, calibration problems appear to be mainly responsible for
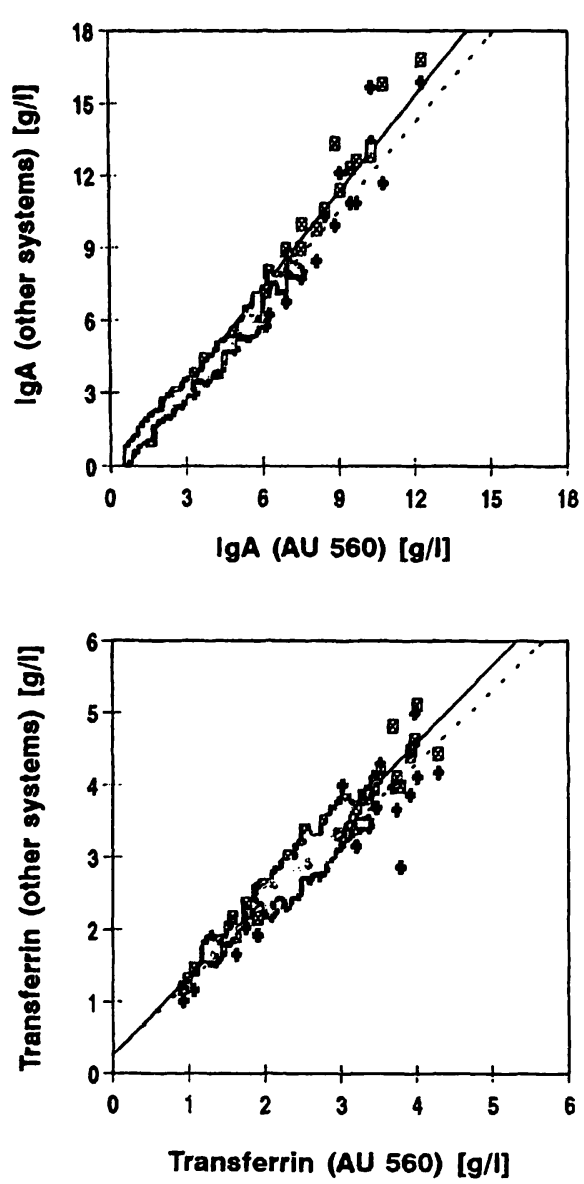

assigned the $y$-axis. The regression lines were calculated according the standardized principal component model.

(— $\otimes):$ QM 300

$(\cdots+.+)$ : Specific

$(--\mathrm{Z})$ : BNA

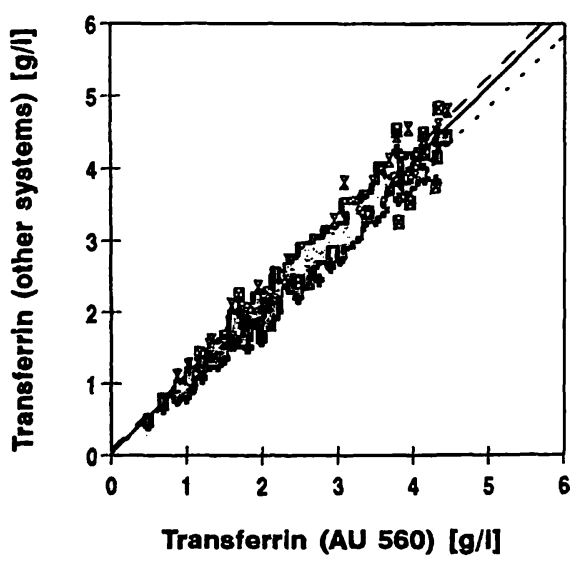


the latter (slope values different from 1). As a matter of fact, mathematical manipulation of the results, using CRM 470-derived factors supplied by the manufacturers, has been shown to substantially improve the intermethod comparability of results in the measurement of a number of serum proteins in a sample-group of reference individuals (10). Previous results on the effect of the calibration procedure (1), and the expected practical impact of the CRM 470 (2) are thereby confirmed.

In this work, by comparing the inter-method behaviour of control materials and of sets of patients' sera over wider concentration intervals, we have assessed the intrinsic characteristic of the "materials" commonly referred to as commutability. According to a previously suggested criterion (9), most of the materials showed commutable, such a low rate of non-commutability events $(<1.5 \%)$ being partly due to' the large variability of the inter-method differences exhibited by patients' sera (5). However (tab. 4), the normalized residuals from patients' sera were distributed as theoretically expected (mean $=0 ;$ standard deviation $=1$ ), whilst those from the control materials were distributed within narrower limits (standard deviation <1) but frequently not
Tab. 3 Linear regression analysis (standardized principal component) of the results from systems comparison, in the assay of patients' sera. Results from the AU 560 system were consistently assigned the $\mathrm{x}$-axis, those from the compared system the $\mathrm{y}$-axis Residual standard deviations $\left(\mathrm{S}_{\mathrm{yx}}\right)$ are shown as a measure of the dispersion around the line.

\begin{tabular}{|c|c|c|c|c|c|c|c|}
\hline Protein & $\begin{array}{l}\text { Compared } \\
\text { system (y-axis) }\end{array}$ & Exp. & $\mathrm{n}$ & $\begin{array}{l}\left.S_{y x}\right) \\
(g / 1)\end{array}$ & $\begin{array}{l}\text { Interval of } \\
x \text {-values }(g / l)\end{array}$ & $\begin{array}{l}y \text {-Intercept } \\
(\mathrm{g} / \mathrm{l})\end{array}$ & Slope \pm S. E. \\
\hline $\begin{array}{l}\text { IgG } \\
\text { IgG }\end{array}$ & $\therefore \quad \begin{array}{ll}\text { QM } 300 \\
\text { SPECIFIC }\end{array}$ & $\begin{array}{l}\text { I } \\
\text { I }\end{array}$ & $\begin{array}{l}100 \\
100\end{array}$ & $\begin{array}{l}1.22 \\
2.14\end{array}$ & $\begin{array}{l}4.33 \div 44.21 \\
4.33 \div 44.21\end{array}$ & $\begin{array}{l}+0.48 \\
+0.99\end{array}$ & $\begin{array}{l}1.06 \pm 0.012 \\
1.08 \pm 0.022\end{array}$ \\
\hline $\begin{array}{l}\operatorname{Ig} A \\
\operatorname{Ig} A\end{array}$ & $\begin{array}{l}\text { QM } 300 \\
\text { SPECIFIC }\end{array}$ & $\begin{array}{l}\text { I } \\
\text { I }\end{array}$ & $\begin{array}{l}100 \\
100\end{array}$ & $\begin{array}{l}0.53 \\
0.61\end{array}$ & $\begin{array}{l}0.68 \div 12.28 \\
0.68 \div 12.28\end{array}$ & $\begin{array}{l}-0.68 \\
-0.58\end{array}$ & $\begin{array}{l}1.33 \pm 0.020 \\
1.23 \pm 0.023\end{array}$ \\
\hline $\begin{array}{l}\text { IgM } \\
\text { IgM } \\
\text { IgM } \\
\text { IgM } \\
\text { IgM } \\
\text { IgM }\end{array}$ & $\begin{array}{l}\text { QM } 300 \\
\text { SPECIFIC } \\
\text { BNA } \\
\text { QM } 300 \\
\text { BNA } \\
\text { APS } 360\end{array}$ & $\begin{array}{l}\text { I } \\
\text { I } \\
\text { I } \\
\text { II } \\
\text { II } \\
\text { II }\end{array}$ & $\begin{array}{l}100 \\
100 \\
100 \\
110 \\
110 \\
110\end{array}$ & $\begin{array}{l}0.36 \\
0.52 \\
0.42 \\
0.36 \\
0.56 \\
0.30\end{array}$ & $\begin{array}{l}0.40 \div 8.69 \\
0.40 \div 8.69 \\
0.40 \div 8.69 \\
0.32 \div 8.56 \\
0.32 \div 8.56 \\
0.32 \div 8.56\end{array}$ & $\begin{array}{l}-0.28 \\
-0.42 \\
-0.35 \\
-0.18 \\
-0.24 \\
-0.11\end{array}$ & $\begin{array}{l}1.00 \pm 0.024 \\
1.38 \pm 0.034 \\
1.62 \pm 0.028 \\
0.83 \pm 0.018 \\
1.36 \pm 0.028 \\
0.92 \pm 0.015\end{array}$ \\
\hline $\begin{array}{l}\text { Transferrin } \\
\text { Transferrin } \\
\text { Transferrin } \\
\text { Transferrin } \\
\text { Transferrin }\end{array}$ & $\begin{array}{l}\text { QM } 300 \\
\text { SPECIFIC } \\
\text { QM } 300 \\
\text { BNA } \\
\text { APS } 360\end{array}$ & $\begin{array}{l}\text { I } \\
\text { I } \\
\text { II } \\
\text { II } \\
\text { II }\end{array}$ & $\begin{array}{l}100 \\
100 \\
110 \\
110 \\
110\end{array}$ & $\begin{array}{l}0.18 \\
0.27 \\
0.20 \\
0.15 \\
0.16\end{array}$ & $\begin{array}{l}0.93 \div 4.29 \\
0.93 \div 4.29 \\
0.50 \div 4.44 \\
0.50 \div 4.44 \\
0.50 \div 4.44\end{array}$ & $\begin{array}{l}+0.26 \\
+0.26 \\
+0.04 \\
+0.08 \\
+0.02\end{array}$ & $\begin{array}{l}1.09 \pm 0.025 \\
1.02 \pm 0.039 \\
1.02 \pm 0.019 \\
1.04 \pm 0.014 \\
0.97 \pm 0.015\end{array}$ \\
\hline
\end{tabular}

Tab. 4 Assessment of commutability: distribution quantities of the two populations of normalized residuals from patients' sera (n from 100 to 110 ) and control materials (n from 17 to 19 ). The normalized residuals from the CRM 470 are tabulated in a separate column for comparison. Results from each alternative system were compared with the $\mathrm{AU} 560$ system.

\begin{tabular}{|c|c|c|c|c|c|c|c|c|c|c|}
\hline \multirow[t]{3}{*}{ Protein } & \multirow{3}{*}{$\begin{array}{l}\text { System } \\
\text { compared }\end{array}$} & \multirow[t]{3}{*}{ Exp. } & \multicolumn{7}{|c|}{ Normalized residuals from } & \multirow[t]{3}{*}{ Line } \\
\hline & & & \multicolumn{3}{|c|}{ Patients' sera } & \multicolumn{3}{|c|}{ Control materials } & \multirow{2}{*}{$\begin{array}{l}\text { CRM } \\
470\end{array}$} & \\
\hline & & & $\mathrm{m}$ & SD & $\begin{array}{l}\text { outside } \\
\pm 3\end{array}$ & $\mathrm{~m}$ & SD & $\begin{array}{l}\text { outside } \\
\pm 3\end{array}$ & & \\
\hline $\operatorname{IgG}$ & QM 300 & I & 0.00 & 1.00 & 0 & -0.10 & 0.28 & 0 & - & 1 \\
\hline $\lg G$ & SPECIFIC & I & 0.00 & 1.00 & 0 & -0.12 & 0.54 & 0 & - & 2 \\
\hline $\lg A$ & QM 300 & I & 0.00 & 1.00 & 2 & 0.10 & 0.52 & 0 & - & 3 \\
\hline $\operatorname{Ig} A$ & SPECIFIC & I & 0.00 & 1.00 & 1 & 0.30 & 0.26 & 0 & - & 4 \\
\hline $\lg M$ & QM 300 & I & 0.01 & 1.00 & 3 & -0.25 & 0.44 & 0 & - & 5 \\
\hline IgM & QM 300 & II & -0.01 & 1.00 & 2 & 0.63 & 0.35 & 0 & 0.83 & 6 \\
\hline IgM & SPECIFIC & I & -0.01 & 1.00 & 1 & -0.54 & 0.55 & 0 & - & 7 \\
\hline IgM & BNA & I & 0.01 & 1.00 & 2 & 0.58 & 0.52 & 0 &.- & 8 \\
\hline IgM & BNA & II & 0.00 & 1.00 & 2 & 1.16 & 0.47 & 0 & 0.74 & 9 \\
\hline IgM & APS 360 & II & 0.00 & 1.00 & 1 & 0.82 & 0.56 & 0 & 0.84 & 10 \\
\hline Transferrin & QM 300 & I & 0.01 & 1.00 & 1 & -2.02 & 0.55 & 0 & - & 11 \\
\hline Transferrin & QM 300 & II & -0.02 & 1.00 & 3 & 1.80 & 0.98 & 3 & 2.12 & 12 \\
\hline Transferrin & SPECIFIC & I & -0.02 & 1.00 & 1 & -1.60 & 0.50 & & - & 13 \\
\hline Transferrin & BNA & II & 0.04 & 1.00 & 1 & 0.90 & 1.44 & $3 \cdot i$ & 1.03 & 14 \\
\hline Transferrin & APS 360 & II & 0.00 & 1.00 & 2 & 0.68 & 1.00 & 1 & 1.50 & 15 \\
\hline
\end{tabular}



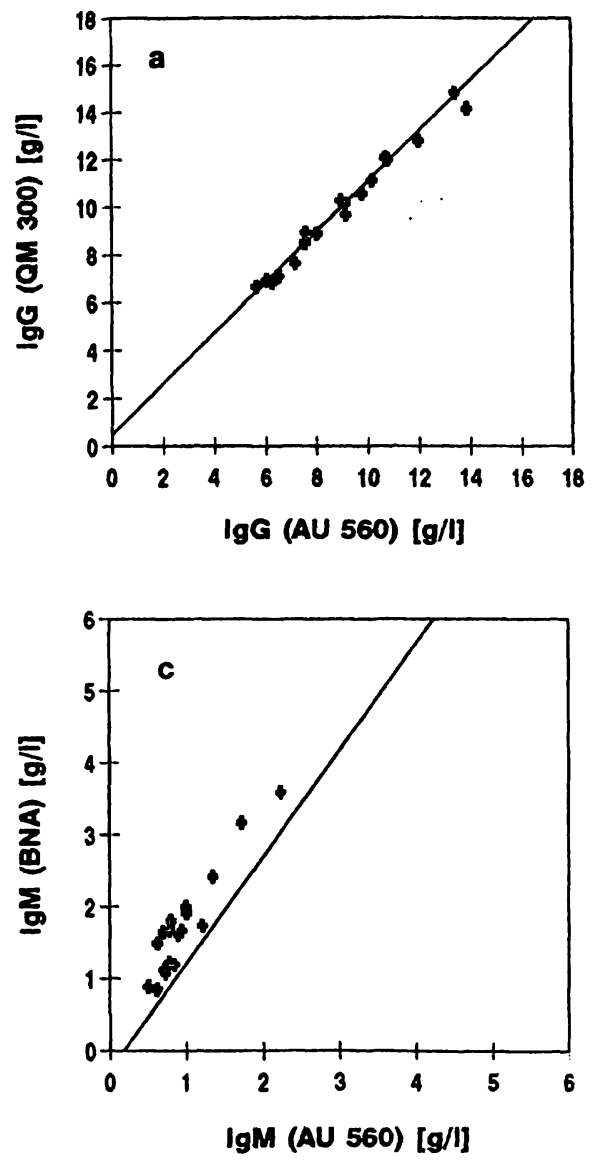

Fig. 3 Representative examples of the inter-method behaviour of control materials (crosses) compared with patients' sera (regression lines, standardized principal component model). Diagrams a, b, c, and $\mathrm{d}$, correspond, respectively, to lines $1,3,9$, and 14 of table 4 .

around 0 . These data mean that the sample-group of materials shows inter-method changes more homogeneous than the sample-group of patients' sera. Nevertheless, and in spite of low frequency of non-commutability events, the two groups differ from each other in their inter-method behaviour: the CRM is closer to the control materials than to patients' sera. Similar behaviour was shown by the control materials for cholesterol measurement (11).

These findings suggest that, in most cases, the intermethod differences measured with either a control material or a fresh serum sample are expected to show statistically significant agreement. Nevertheless, when many of the tested materials (including the CRM 470) are used to directly check for (control), or to pursue (calibration)

\section{References}

1. Bullock DG, Dumont G, Vassault A, Aguzzi F, Chambers RE, Milford Ward A, et al. Immunochemical assays of serum proteins: a European external quality assessment survey and the effects of calibration procedures on interlaboratory agreement. Clin Chim Acta 1990; 187:21-36.

2. Whicher JT, Ritchie RF, Johnson AM, Baudner S, Bienvenue $J$, Blirup-Jensen $S$, et al. New international reference preparation for proteins in human serum (RPPHS). Clin Chem 1994; 40:934-8.

3. Fasce CF, Jr, Rej R, Copeland WH, Vanderlinde RE. A discussion of enzyme reference materials: applications and specifications. Clin Chem 1973; 19:5-9.
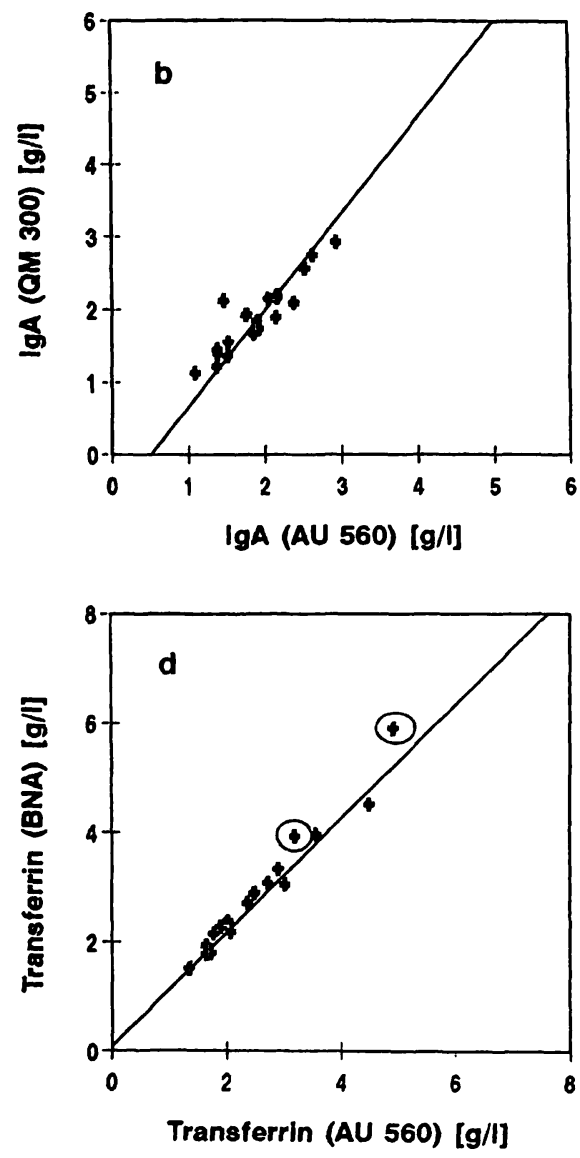

In diagrams $\mathrm{a}$ and $\mathrm{b}$ the points distribute on the two sides of the line, in diagram $c$ and $d$ they distribute mainly or exclusively on one side of the line. In diagram $d$ two points outside the line by more than 3 residual standard deviations are circled.

consistency in measurements by different methods, some residual differences may still exist when these methods are applied to fresh sera.

Therefore, transfer of accuracy and accurate inter-method comparison are best performed with protocols that also include direct method comparison on a large series of split serum samples $(12,13)$. Alternatively, the commutability of the materials should be verified. Although some of the differences observed between experiments I and II may be due to differences in the sets of patients' sera, it seems that both the inter-method differences and the degree of commutability of the control materials are sensitive to variations in the assay protocol. This further suggests the need for a frequent check of such properties.

4. Rej R, Jenny RW, Bretaudiere JP. Quality control in clinical chemistry: characterization of reference materials. Talanta $1984 ; 31: 851-62$.

5. Franzini C. Commutability of reference materials in clinical chemistry. JIFCC 1993; 5:186-93.

6. Rej R. Accurate enzyme activity measurements. Two decades of development of the commutability of enzyme quality control materials. Arch Pathol Lab Med 1993; 117:352-64.

7. Galletta G, Arcangeli L, Scapellato L. Commutability of control materials in immunonephelometric and immunoturbidimetric measurement of some specific serum proteins [abstract]. Eur J Clin Chem Clin Biochem 1994; 32:A17. 
8. Haeckel R, Bablok W, Goldschmidt HMJ, Müller HAG, Meyers W, Stockmann W, et al. Recommendations for the biometrical evaluation of method comparison results from patients' samples. DG Klin Chem Mitteilungen 1994; 25:32-4.

9. Van Helden WCH, Visser RWJ, Van Den Bergh FAJ-TM, Souverijn JHM. Comparison of inter-method analytical variability of patient sera and commercial quality control sera. Clin Chim Acta 1979; 93:335-47.

10. Aguzzi F, Gasparro C, Somenzini M, Calatroni S. I nuovi valori di riferimento per le 14 sieroproteine del CRM 470 (RPPHS). Dati preliminari. Biochim Clin 1994; 18:612-6.

11. Franzini C, Luraschi P. Commutability of control materials in cholesterol measurements. Scand J Clin Lab Invest 1993; 53:51-5.
12. Miller WG, Rhodes DJ, Moore CJ. A calibration protocol for serum-based secondary standards. Clin Chem 1982; 11:2195-200.

13. Cooper GR, Myers GL. Reference system for cholesterol measurements. Scand J Clin Lab Invest 1990; 198 Suppl 50:27-1.

Received July 3/October 5, 1995

Corresponding author: Prof. Carlo Franzini, Universita' di Milano, Istituto di Scienze Biomediche, Ospedale L. Sacco, Via G. B. Grassi, 74, I-20157 Milano, Italy 